\title{
The autopsy evaluation of "straightforward" fire deaths
}

\author{
Roger W. Byard ${ }^{1}$
}

Accepted: 7 August 2017 /Published online: 23 August 2017

(C) Springer Science+Business Media, LLC 2017

Deaths caused by fires are not uncommon in forensic practice but can be amongst the most difficult to investigate. Not only is important scene evidence often destroyed in the conflagration, but so may be all, or part, of the body under investigation. Fire deaths arise from a wide variety of events that range from isolated single domestic accidents initiated by a candle burning curtains to mass disasters involving dozens of victims in nightclub fires, or from arson for insurance purposes to culturally determined homicides in the form of dowry murders $[1,2]$. Autopsy evaluations have to be adapted for each of these situations and may be complicated by issues with identification, determination of the cause and manner of death, and interpretation of the potential significance of heat-related artefacts such as bone fractures and heat epidural hematomas [1]. Any approach to a fire death that assumes that all will be straightforward should be quickly abandoned, as each case must be examined with an open mind and an awareness of the numerous pitfalls that may be encountered.

Deaths in fires may occur from a variety of mechanisms. In house fires where there may be low intensity burning of household effects and furnishings for some time away from victims, there may be minimal damage to bodies, with deaths occurring from inhalation of the products of combustion. This usually involves carbon monoxide ( $>50-60 \%$ saturation), but may also include cyanide if plastics have been burnt. Testing for the latter may therefore provide useful information in such deaths [3].

Roger W. Byard

roger.byard@sa.gov.au

1 Discipline of Anatomy and Pathology, School of Medicine, The University of Adelaide, Frome Road, Level 3 Medical School North Building, Adelaide, SA 5005, Australia
Bodies may show characteristic cherry-pink discoloration typical of carbon monoxide exposure, and the upper airways should be carefully examined for evidence of smoke inhalation. This may take the form of soot soiling of the nares and oropharynx with soot-stained mucus lining the trachea and main bronchi [4]. Unfortunately in cases where there has been extensive burning and charring, the integrity of the airways may have been compromised and soot may be present within air passages purely from external contamination and not from inhalation. This may be exacerbated if there has been extensive destruction of the building with collapse of internal walls and ceilings causing further damage to the remains.

In cases where there has been more intense burning, bodies may range from having the characteristically pugilistic postures of the deeply charred, to forming mere piles of carbonized bones and ashes. This is clearly a problem in cases of multiple deaths, for example after bush (brush) fires, where there may be comingling of remains [5]. Teeth are often essential for identification, particularly if skin, soft tissues and fluids have all been destroyed, and so steps should be taken at the scene to use glues and fixatives to reinforce and protect dental material prior to transport [6-8].

A major issue in fire deaths lies in determining whether a decedent was dead before a fire started. This may have an entirely innocent explanation if, for example, an elderly individual has collapsed from a lethal cardiac dysrhythmia and knocked a heater over during the terminal fall. Alternatively, setting fire to a dwelling where a body has been dumped is a well-recognized method of attempting to disguise a homicide. It should also be appreciated that levels of carbon monoxide that are not normally regarded as lethal $(25 \%)$ may still have fatal consequences in those with significant underlying cardiovascular disease [3]. In other cases where there has been very rapid burning with fast consumption of environmental oxygen, for example with accelerants or a bush fire [9], a 
"flash fire" effect may also cause death from oxygen deprivation with minimal levels of carbon monoxide being present. The lack of carbon monoxide in the peripheral blood in circumstances such as this should not therefore be taken as evidence that death had occurred before the fire began [3].

At autopsy, skin slippage may have occurred which could interfere with fingerprint identification [1]. Careful layer dissection and examination of remaining tissues and organs should be undertaken to look for evidence of injuries or lesions that do not seem to fit with the observed scene. This is of course sometimes complicated by putrefactive changes that have occurred due to heating of the body by the fire, and the prolonged time that it may have taken to locate the remains and to safely remove them [10]. In addition to soot staining, the upper airways may show burns to the tongue, pharynx, glottis, larynx and tracheobronchial tree if there has been inhalation of hot air. This may also induce prominent pulmonary edema [3].

Intense heat also results in fracturing of bones and in socalled epidural heat hematomas, where a collection of heated blood accumulates between the dura and skull not related to antemortem fractures [4]. It is differentiated from an antemortem collection by having a similar carboxyhemoglobin level to the peripheral blood [3]. An additional artefact that is created by intense temperature is splitting, when heated skin contracts and tears. This most often occurs over the head, extensor surfaces and joints and may be mistaken for antemortem wounding. Although there is no blood in these splits, the distinction between an ante- or postmortem effect may not always be easy [3, 4]. The separation of antemortem injuries from postmortem heat artefacts is a particular problem in high speed vehicle crashes where there has been subsequent incineration; i.e. determining whether death was due to significant blunt force impact or incineration may not be possible.

The nature of fire deaths also varies depending on age, with the very young and old being particularly vulnerable. Both age groups may have limited understanding of the dangers of fire, and also reduced cognitive ability to plan an escape. It is, for example, well recognized that young children will try to hide from a fire rather than leaving the area. Car fires are a good example of this, where children playing with lighters may set a car on fire and hide in the back seat rather than exiting through the doors [11].

While most fire deaths are accidental, suicides and homicides by fire do occur, although self-immolation is a rare form of suicide in Western, compared to other, countries [12]. For example, the highest incidence of suicidal self-burning in local South Australian data (6\% of cases) occurred in adolescence, most likely reflecting lack of access to other more usual methods favored by adults [13]. Homicide by burning is also rare in Western countries, with most cases involving individuals who have died when buildings have been set on fire. In some situations accelerants such as kerosene may be poured on victims and ignited, as in dowry murders in India where there are often attempts to make the deaths appear accidental due to kitchen fires [2]. Disguising homicides by burning the body and its surroundings has already been referred to.

In its simplest form, a fire death may occur when a socially isolated individual drops a cigarette while intoxicated and accidentally sets fire to his or her bed. Unfortunately even this does not escape from added complexities, with occasional cases being attributed to "spontaneous human combustion". This urban myth refers to an alleged situation where a victim has purportedly burst into flames and then been incinerated [14]. Despite recent use of the term in Western medicolegal circles the most likely scenario is of an obese alcoholic wrapped in blankets or coverings who has dropped a cigarette and then smolders away due to a type of "wick" effect. Thus, while there is no doubt that combustion has occurred, it is far from spontaneous [14].

In summary, the safest approach to assessing a fire death is to assume that there is seldom going to be anything resembling a straightforward case. Once that point has been appreciated, then the case can be processed in an orderly and meticulous fashion with appropriate attention being duly paid to all aspects of the history, scene, autopsy and ancillary evaluations. In this way clear documentation of findings can be ensured with maintenance of an appropriate chain of custody. This is really the only "straightforward" way to handle these potentially highly complex cases.

\section{References}

1. Prahlow J. Autopsy findings: fire deaths. In: Payne-James J, Byard RW, editors. Encyclopedia of Forensic and Legal Medicine, $2^{\text {nd }}$ ed. Vol. 1.Oxford: Academic Press; 2016. pp. 323-35.

2. Menezes RG, Nagaraja SB, Krishna K, Devadass PK. Deaths: dowry killings. In: Payne-James J, Byard RW, editors. Encyclopedia of forensic and legal medicine, vol. 2. 2nd ed. Oxford: Academic Press; 2016. p. 67-73.

3. Saukko P, Knight B. Burns and scalds. In: Knight's forensic pathology, $3^{\text {rd }}$ ed. New York: CRC Press; 2016. pp. 311-324.

4. Prahlow J, Byard RW. Burns and fire-related deaths. In: Prahlow J, Byard RW, editors. Atlas of forensic pathology. New York: Springer Publishers; 2012. p. 753-84.

5. Cordner SM, Woodford N, Bassed R. Forensic aspects of the 2009 Victorian bushfires disaster. Forensic Sci Int. 2011;205:2-7.

6. Henry TE, Graham MA. Deaths associated with fires and burns In: Froede RC, editor. Handbook of Forensic Pathology, $2^{\text {nd }}$ ed. Northfield Il: College of American Pathologists; 2003. pp. 219 224.

7. Berketa JW. Maximising post-mortem oral-facial data to assist identification following severe incineration. Forensic Sci Med Pathol. 2014;10:208-16.

8. Berketa J, James H, Langlois N, Richards L, Pigou P. Use of nonvolatile agent to stabilize severely incinerated dental remains. Forensic Sci Med Pathol. 2015;11:228-34.

9. Byard RW, Gilbert JD, Kostakis C, Heath K. Circumstances of death and diagnostic difficulties in brushfire fatalities. J Forensic Sci. 2012;57:969-72. 
10. Zhou C, Byard RW. Factors and processes causing accelerated decomposition in human cadavers. An overview J Forensic Leg Med. 2011;18:6-9.

11. Byard RW, Lipsett J, Gilbert J. Fire deaths in children in South Australia from 1989 to 1998. J Paediatr Child Health. 2000;36: 176-8.

12. Alunni V, Grevin G, Buchet L, Gaillard Y, Quatrehomme G. An amazing case of fatal self-immolation. Forensic Sci Int. 2014;244: e30-3.
13. Byard RW, Markopoulos D, Prasad D, Eitzen D, James RA, Blackbourne B, et al. Early adolescent suicide: a comparative study. J Clin Forensic Med. 2000;7:6-9.

14. Byard RW. The myth of spontaneous human combustion. Forensic Sci Med Pathol. 2016;12:350-2. 